\title{
Broad Spectrum Algae Compounds Against Viruses
}

\begin{abstract}
Jacqueline Graff Reis ${ }^{1}$, Rafael Dorighello Cadamuro' ${ }^{1}$, Ariadne Cristiane Cabral ${ }^{1,2}$, Izabella Thaís da Silva ${ }^{1,3}$, David Rodríguez-Lázaro ${ }^{4,5}$ and Gislaine Fongaro ${ }^{\text {1* }}$

${ }^{1}$ Laboratory of Applied Virology, Department of Microbiology, Immunology, and Parasitology, Federal University of Santa Catarina, Florianópolis, Brazil, ${ }^{2}$ Department of Dentistry, Federal University of Santa Catarina, Florianópolis, Brazil, ${ }^{3}$ Department of Pharmaceutical Sciences, Federal University of Santa Catarina, Florianópolis, Brazil, ${ }^{4}$ Microbiology Division, Faculty of Sciences, University of Burgos, Burgos, Spain, ${ }^{5}$ Research Centre for Emerging Pathogens and Global Health, University of Burgos, Burgos, Spain
\end{abstract}

The pharmaceutical industry is currently trying to develop new bioactive compounds to inactivate both enveloped and non-enveloped viruses for therapeutic purposes. Consequently, microalgal and macroalgal bioactive compounds are being explored by pharmaceutical, as well as biotechnology and food industries. In this review, we show how compounds produced by algae include important candidates for viral control applications. We discuss their mechanisms of action and activity against enveloped and non-enveloped viruses, including those causing infections by enteric, parenteral, and respiratory routes. Indeed, algal products have potential in human and animal medicine.

Keywords: virucidal, algae, antiviral, health, mechanisms

\section{INTRODUCTION}

Many significant zoonotic pathogens are viruses and they have substantial infection-related impacts on public health worldwide. Non-enveloped enteric viruses are persistent in the environment (in water, soil and sewage, and on surfaces), resisting $\mathrm{pH}$ ranges of up to 3 to 9 , temperature variations, and radiation (Evans, 1982; Taylor et al., 2001; Olival et al., 2017). Such viruses are a common cause of foodborne contamination (Carter, 2005; Elizondo-Gonzalez et al., 2012), which is responsible for 1.1 million hospitalizations and 218,000 deaths/year of children in countries with poor sanitary conditions (Patel et al., 2008). Enveloped viruses, with their environmental dissemination by air and aerosols, are responsible for pandemic events such as those involving Influenza and Coronavirus (Medina and García-Sastre, 2011; Chiu et al., 2012; Wang et al., 2018; Glass et al., 2020). Some enveloped viruses demonstrated high capability to cause epidemic episodes, such as Dengue virus on 2019 infecting 6,162,394 and causing death of 3,930 people. Ebola virus on Uganda/Congo region between 2018/2020, causing 3,453 infections and 2,273 deaths, other viruses as Nipah, Yellow fever and Zika caused epidemics through the worldwide (Agca et al., 2021; Anand et al., 2021; Yoon et al., 2021).

Enteric and respiratory viruses present enormous challenges both for human and animal medicine, and there is therefore a need for new antiviral solutions for fighting viruses with their worldwide economic and social consequences. Recent respiratory viral epidemics such as the worldwide outbreaks of swine flu, avian flu, and coronavirus has increased interest in the development of antiviral drugs (Prasse et al., 2010; Feng et al., 2018; Ye et al., 2020). Exploring natural compounds is an important approach to obtaining new virucides and antivirals. Macroalgal marine polysaccharides are potential candidates for human and animal medicine and have attracted 
the attention of the scientific community for applications in biotechnology (Dias et al., 2012; Wang et al., 2012).

Macroalgae are a phylogenetically artificial group of multicellular, macroscopic, eukaryotic, photoautotrophic organisms, mostly benthic (many being commonly known as seaweed), which are classified into three large groups: Chlorophyta (green algae), Rhodophyta (red algae), and Phaeophyceae (brown algae) (Leandro et al., 2019).

The components of macroalgae vary from simple to complex compounds, including polysaccharides (e.g., fucoidan, alginate, laminarin, carrageenan), phenolics and phlorotannins (e.g., flavonoids, lignans, tannins), protein and peptides (themselves made up of amino acids including leucine, glutamic acid, tryptophan), lipids, terpenoids and steroids (e.g., carotenoids), vitamins and minerals (Spolaore et al., 2006; Onofrejová et al., 2010; Balboa et al., 2013). Freshwater and marine microalgae contain compounds of high relevance to health, for example vitamins, proteins with essential amino acids, fatty acids, polysaccharides, minerals, enzymes, fibers and photosynthetic pigments such as carotenoids and chlorophylls (Montalvão et al., 2016; Silva et al., 2018). Various bioactive compounds from algae are attracting growing interest because of their antitumor, antiviral, anticoagulant, and antioxidant properties (Wang et al., 2012; Wang et al., 2018).

Algae have a variety of broad-spectra activities against viruses and low cytotoxicity, both in vitro and in vivo. However, their potential is still underexplored by the pharmaceutical industry, and only $9 \%$ of medicines of natural origin come from algae (Kumar Jha and $\mathrm{Zi}$-Rong, 2004). Besides that, there are many in vitro studies proving the antiviral effects of algae, there have been few studies of their efficiency in vivo and in the environment. Indeed, there is an urgent need for further investigations of this type (Rosa et al., 2020).

This review presents selected compounds from algae as candidates for the control of viruses with applications in the phytochemical, pharmaceutical, and sanitizing sectors.

\section{OBTAINING CRUDE AND FRACTIONATED EXTRACTS FOR ANTIVIRAL AND VIRUCIDAL ASSAYS FROM ALGAE}

Bioactive compounds can be extracted from macroalgae or microalgae using various methods. The most common for extracting bioactive compounds from marine samples is solid-liquid extraction (SLE), involving solvents to extract soluble constituents from a solid or semisolid matrix. The downside of this method is its long extraction time and high solvent consumption (Wang et al., 2018; Jacobsen et al., 2019). Other relevant techniques are solid-phase extraction (SPE), supercritical fluid extraction (SFE), ultrasound-assisted extraction (UAE), microwave-assisted extraction (MAE), and pressurized liquid extraction (PLE); SFE, UAE, and MAE are the most commonly used for macroalgae (Kaufmann and Christen, 2002; Ciko et al., 2018).
Obtention of compounds of interest from marine macroalgae and microalgae involves the following major steps: (1) collection and taxonomic identification of samples; (2) drying; (3) extraction through the use of solvent; (4) filtration and concentration by evaporation (Fayzunnessa et al., 2011; El-Baz et al., 2013; Choi et al., 2014).

Cytotoxic, antivirus, and virucide assays and other cell culture techniques are used to screen candidates. Cytotoxic assays identify compounds that are toxic to healthy cells. A typical protocol is to cultivate an appropriate cell line in an Eagle medium at $30^{\circ}$ with $5 \%$ of $\mathrm{CO}_{2}$ in a layer in a 96 -well plate, and applying serial dilutions of compounds of interest. After 7 days of incubation, viable cells are revealed by using chemicals such as sulphorhodamine B and tetrazolium dye 3-(4,5-dimethylthiazol2-yl)-2,5-diphenyltetrazolium bromide (MTT) (Chacon et al., 1996; Vichai and Kirtikara, 2006).

Antiviral assays identify compounds that for example inhibit viral replication. Such assays generally involve placing viruses in contact with permissive cells and allowing the cycle of replication to begin. The antiviral compound being tested is then applied and successfully replicated viruses counted as plaque-formed units (PFU) after revelation by staining cells with crystal violet. Percentages of viral inhibition and of cells free of infection can then be calculated.

Virucidal assays identify compounds that kill viruses, by for example, inactivating recognition proteins. Viruses are exposed to the sample under study and then a known quantity of virus is used to inoculate cells in 6-well plates; in some protocols, agarose is use to stabilize neighboring cells to favor the transmission of viruses. Viral neutralization is quantified by counting PFU after viable cells are colored with crystal violet (Jothikumar et al., 2005). This assay is important for evaluating compounds that may be able to inactivate viruses in the environment (Victoria et al., 2009; Rigotto et al., 2011; Célia da Silva Lanna et al., 2019).

\section{DISCUSSION}

Algae and their extracts have numerous applications and have historically stimulated significant economic interest, mainly as a source of new drugs such as antivirals. therefore, we report crude extracts and compounds isolated from algae that showed antiviral activity against both enveloped and non-enveloped viruses. Some examples of these compounds and extracts from algae with antiviral activity are listed in Table $\mathbf{1 .}$

\section{Crude Extracts From Algae Against Viruses}

Red seaweed Osmundaria obtusiloba has been reported to have higher antiviral and virucidal effects against the Chikungunya virus (CHIKV) than ribavirin, which is used as a drug to control the virus (Cirne-Santos et al., 2019). The $\lambda$ - and $\iota$-carrageenans obtained from Osmundaria obtusiloba have potent antiviral activity against dengue virus type 2 (DENV-2) and type 3 (DENV3) (Talarico and Damonte, 2007).

An ethanol extract from the microalgae Spirulina platensis has antiviral effects against Adenovirus type 40, a non-enveloped 
TABLE 1 | Species and compounds from algae used as antivirals.

\begin{tabular}{|c|c|c|c|}
\hline Species & Compounds & Applications & References \\
\hline \multicolumn{4}{|l|}{ Macroalgae } \\
\hline- & lota-carrageenan & $\begin{array}{l}\text { HRV1A, HRV2, HRV8, HRV14, } \\
\text { HRV16, } \\
\text { HRV83, HRV84 }\end{array}$ & Grassauer et al., 2008 \\
\hline Stypopodium zonale & Meroditerpene epitaondiol & HMPV & \\
\hline Laminaria japonica & Sulphated polysaccharide fucoidan & H5N1, RSV & Cao et al., 2016 \\
\hline $\begin{array}{l}\text { Chondrus armatus } \\
\text { Laminaria cichorioides, Laminaria japonica }\end{array}$ & ı-carrageenans, fucoidan & Hantavirus & Pavliga et al., 2016 \\
\hline Griffithsia sp. & Protein griffithsin & $\begin{array}{l}\text { SARS-CoV (Urbani strain), HIV, } \\
\text { HCV, HSV-2, JEV, PEDV }\end{array}$ & $\begin{array}{c}\text { Mori et al., 2005, O'Keefe et al., 2009, } \\
\text { O'Keefe et al., 2010, Meuleman et al., } \\
\text { 2011, Ishag et al., 2013, Takebe et al., } \\
\text { 2013, Levendosky et al., } 2015\end{array}$ \\
\hline Griffithsia sp. & Grifonin-1 & HIV-1 & Micewicz et al., 2010 \\
\hline Laurencia obtusa & Polysaccharide & $\mathrm{HCV}$ & Gheda et al., 2016 \\
\hline Cladosiphon okamuranus & Fucoidan & DENV-2 & Hidari et al., 2008 \\
\hline- & $\lambda$-carrageenans, ı-carrageenans & DENV-2, DENV-3 & Talarico and Damonte, 2007 \\
\hline- & Fucoidan & NDV & Elizondo-Gonzalez et al., 2012 \\
\hline Cladosiphon okamuranus & Fucoidan & CDV & Trejo-Avila et al., 2014 \\
\hline Eisenia bicyclis & Dieckol/phlorofucofuroeckol-A & FCV, murine norovirus & Choi et al., 2014, Eom et al., 2015 \\
\hline Nicotiana benthamiana & Griffithsin/Carrageenan & HSV-2/human papillomavirus & Levendosky et al., 2015 \\
\hline Schizymenia binderi & Sulphated galactan & HSV-1, HSV-2 & Matsuhiro et al., 2005 \\
\hline Gracilaria corticata & Sulphated galactan & HSV-1, HSV-2 & Mazumder et al., 2002 \\
\hline $\begin{array}{l}\text { Padina pavonica, Sargassum vulgare, } \\
\text { Pterocladia capillace, Laurencia obtusa }\end{array}$ & Sulphated polysaccharides & $\mathrm{HCV}$ & Gheda et al., 2016 \\
\hline \multicolumn{4}{|l|}{ Microalgae } \\
\hline Chlorella vulgaris & Polysaccharide & HSV-1 & Santoyo et al., 2010 \\
\hline Gyrodinium impudium & Sulphated polysaccharide p-KG03 & IAV, EMCV & Kim et al., 2012 \\
\hline Spirulina platensis & Sulphoquinovosyl diacylglycerol & $\begin{array}{l}\text { Adenovirus } 40-7 \text {, } \\
\text { Coxsackievirus B4, Astrovirus } \\
\text { type 1, Rotavirus Wa, HSV-1 }\end{array}$ & Abdo et al., 2012; El-Baz et al., 2013 \\
\hline Cochlodinium polykrikoides & Sulphated polysaccharides A1 and A2 & $\begin{array}{l}\text { Influenza A and B viruses, } \\
\text { RSV-A, RSV-B }\end{array}$ & Hasui et al., 1995 \\
\hline Spirulina platensis & Calcium spirulan & $\begin{array}{l}\text { HIV1, HIV2, HSV1, HSV2, } \\
\text { HCMV, MuV, IAV }\end{array}$ & Hayashi et al., 1996 \\
\hline Porphyridium cruentum & - & HH3, W, ASFV, VHSV & Fabregas et al., 1999 \\
\hline Chlorella autotrophica & - & VHSV, ASFV & Fabregas et al., 1999 \\
\hline
\end{tabular}

virus (Abdo et al., 2012). This virus causes gastroenteritis and mortality especially in children. S. platensis also has antiviral effects against Adenovirus type 7, Astrovirus type 1, Coxsackievirus B4 and Rotavirus Wa strain (El-Baz et al., 2013), all of which cause gastroenteritis in humans.

Gyrodinium impudium is a marine microalga with antiviral effects against encephalomyocarditis (EMCV) non-enveloped viruses. EMCV infection causes death among pigs in production units, primates in research centers, and animals in zoos (Kim et al., 2012).

Extracts of some algae have been fed to some types of shrimp to reduce the impact of the white spot syndrome virus (WSSV); this macroalgae and microalgae diet appears to have improved innate immunity and increased the resistance of shrimp to infection by WSSV (Chotigeat et al., 2004; Immanuel et al., 2012; Sivagnanavelmurugan et al., 2012; Charoonnart et al., 2019). Seaweed extracts have also been used in fish diets and have shown promising antiviral effects against the salmon anaemia virus (ISA) and the enveloped RNA virus (Lozano et al., 2016).

\section{Biocompounds Isolated From Algae Against Viruses}

A wide variety of compounds obtained of micro and macroalgae has already been explored and tested against viruses and their cell infection capabilities.

Several studies of macroalgae compounds have shown promising antiviral effects against viruses that cause animal diseases causing serious economic losses. There are no effective treatments, either antivirals or vaccines, currently available against many of these diseases. A study in 2012 reported that the brown algae compound fucoid had an antiviral effect, albeit weak, against the Newcastle virus (NDV), which causes serious diseases in poultry and thereby substantial financial loss (Elizondo-Gonzalez et al., 2012). 
The first seaweed compound with antiviral activity against Canine Distemper Virus (CDV), a morbillivirus related to the measles virus that infects dogs and other carnivores (Trejo-Avila et al., 2014), was reported in 2014. In the same year, another report showed the antiviral potential of brown algae products against norovirus infections using the Feline Calicivirus as a model (Choi et al., 2014).

The Griffithsin protein (GRFT protein), produced by a red alga called Griffithsin sp., has activity against viruses such as the human immunodeficiency virus (HIV), hepatitis C virus (HCV), human papillomavirus, herpes simplex virus $2(\mathrm{HSV}-2)$ and the Japanese encephalitis virus (JEV), the most frequent cause of viral encephalitis in Asia (Ishag et al., 2013; Takebe et al., 2013). GRFT also shows antiviral activity against respiratory viruses including SARS-CoV (Urbani strain), coronaviruses (HCoV-NL63 group and $\mathrm{HCoV}-\mathrm{OC} 43$ group) and infectious bronchitis virus (IBV; Mori et al., 2005; O’Keefe et al., 2009, 2010; Meuleman et al., 2011; Ishag et al., 2013; Takebe et al., 2013; Levendosky et al., 2015; Lusvarghi and Bewley, 2016). Studies with SARS-COV suggest that the GRFT also can reduce the overall viral load, and it acts by binding to the peak glycoprotein at the start of an infection and as an immunomodulator (O'Keefe et al., 2009, 2010). The GRFT protein of red algae is also effective against the porcine diarrhoea virus (PEDV), which causes deaths and large economic losses in the swine industry (Li et al., 2019).

Human noroviruses cause gastroenteritis and phlorotannins from macroalgae have been reported to be active against murine norovirus (MNV), a model for human noroviruses (Eom et al., 2015).

The red seaweed compound carrageenan prevents the replication of Rhinoviruses (HRV1A, HRV2, HRV8, HRV14, HRV16, HRV83, and HRV84), which are more common causes of infection than any other respiratory virus. Carrageenan has also been reported to help improve symptoms of common cold and reduce high viral loads (Grassauer et al., 2008; Eccles et al., 2010). The meroditerpene epitaondiol extracted from brown macroalgae has virucidal activity the human metapneumovirus (HMPV), another respiratory virus, and inhibits the penetration of viral particles into cells (Mendes et al., 2010).

Fucoidan and another polysaccharide from a brown seaweed have virucide activity against Influenza A (H5N1), Hantavirus and Respiratory syncytial virus (RSV), and also other nonrespiratory viruses (Deryabin et al., 2014; Cao et al., 2016; Pavliga et al., 2016).

A sulfated polysaccharide was isolated from the microalgae Spirulina platensis and called calcium spirulana (Ca-SP), this isolate showed antiviral activity against replication of several enveloped viruses, including Herpes simplex virus type 1, human cytomegalovirus, measles virus, mumps virus, influenza A virus, and HIV-1 (Hayashi et al., 1996).

\section{Viral Action Mechanism From Bioactive Algae}

Viruses are obligatorily intracellular parasites; they need to invade cells and hijack cellular machinery to replicate. Enveloped viruses tend to fuse their membrane to the cell membrane to release the genome into the cytoplasm of the host using cytoplasmic endosomes. Fusogenic peptides active at low $\mathrm{pH}$ facilitate access to cytoplasmic endosomes; thus, preventing $\mathrm{pH}$ lowering by molecules released by cells inhibits virion fusion. Non-enveloped viruses, such as enteroviruses, accumulate in endosomes which are highly acidic. Recognition depends on the activity of receptors on the surface of the cells, where the virus binds. Most enteroviruses bind $\alpha 2 \beta 1$ integrin and adenoviruses and coxsackieviruses use adenovirus and coxsackie receptors (Belgerson et al., 1997; Marjomäki et al., 2015). Viruses with an RNA genome initiate their translation and transcription in the cytoplasm, such that they are specific potential targets for viral inhibitors inside the cell. DNA viruses need to penetrate the nucleus to start the process of replication. During translation and transcription, there is an abundance of proteins and viral polymerases, which are also potential targets for inhibition. Nonenveloped viruses are assembled in the cytoplasm in general, and this is followed by cell lysis and thus release of infectious viral particles (Linnakoski et al., 2018).

The antiviral mechanism of compounds obtained from algae is generally related to their specific structure and type of virus. Thus, each algae biomolecule may have a distinct mechanism to inactivate different types of viruses. Some studies suggest that one of the mechanisms of action involved in viral inactivation by algae is due to algal cells having a negatively charged surface which, interacting with the positive charge present in viruses or their cell surfaces, can prevent entry and cellular virus replication (Buck et al., 2006; Grassauer et al., 2008; Branyikova et al., 2018; Eccles, 2020). Furthermore, this antiviral mechanism that algae present is due to the synergistic effect that can occur with the combined use of different compounds present in these algae (RosalesMendoza et al., 2020). Some mechanisms of action of distinct and several compounds from algae with antiviral potential are described below.

Sulphated polysaccharides from seaweed have antiviral effects by acting at the beginning of the virus infection, interfering with virus adsorption and internalization (Mazumder et al., 2002; Talarico et al., 2004; Matsuhiro et al., 2005; Wang et al., 2012).

The antiviral action of fucoidan consists of blocking viral adsorption, inhibiting viral penetration and replication, and heavily suppressing virus-induced syncytium (Ponce et al., 2003; Mandal et al., 2007; Trejo-Avila et al., 2014).

Iota-carrageenan from red marine algae acts against infection by influenza virus through direct binding of the polymer to the viral particles, thereby preventing adsorption onto cell receptors and subsequent internalization, iota-carrageenan has a long chain of negatively charged molecules that attract and capture positively charged viruses and prevent them infecting cells (Leibbrandt et al., 2010; Eccles, 2020). Iotacarrageenan also can bind to the surface of the rhinovirus and causes inhibition of the virus's binding to cell receptors (Grassauer et al., 2008). Iota-carrageenan has an inhibitory effect also after the virus enters the cell, blocking mandatory conformational changes of rhinovirus, Iota-carrageenan acts on the occlusion of the virion surfaces involved in binding to the cellular proteins involved in the infectious process, which can prevent replication and also generate 
defective viral particles (Buck et al., 2006; Grassauer et al., 2008).

Carrageenan from red seaweed adsorbs Enterovirus 71 particles, consequently preventing the viruses from entering cells (Chiu et al., 2012). Both $\lambda$ - and $\iota$-carrageenans can effectively interfere with the adsorption and internalization of DENV when added at the same time as the virus or shortly after infection.

Griffithsin protein from the macroalga Griffithsia sp. has the ability to bind to specific oligosaccharides in the glycoproteins in the virus envelope and block viral entry, GRFT was active against SARS-CoV and HCoV-NL63 using protein-protein interactions for viral targeting, and for $\mathrm{HCoV}-\mathrm{OC} 43$ and $\mathrm{IBV}-\mathrm{CoV}$ utilize protein-carbohydrate interactions for viral attachment (O'Keefe et al., 2010).

An extract from the brown algae Laminaria japonica has a polysaccharide that efficiently inhibits RSV replication, and the mechanism of action depends on interferon regulatory factor 3 (IRF-3)-mediated interferon-alfa (IFN- $\alpha$ ) secretion (Cao et al., 2016).

The antiviral effects of macroalgae extracts against the HMPV virus involve interaction with the viral particles outside the cells and thereby preventing infection. Meroditerpenoids of this species have both virucidal effects and the capacity to inhibit the penetration of viral particles into cells. The binding of HMPV to heparan sulfate involves charge-charge, heparan sulfate blocks the binding of HMPV to the receptor and this occlusion inhibits infection of cells (Klimyte et al., 2016).

Many groups who have demonstrated that compounds and extracts from macroalgae have antiviral effects report the need for studies to elucidate the mechanisms of action of the bioactive compounds (Choi et al., 2014; Eom et al., 2015). Figure 1 illustrates various mechanisms of antiviral activity of compounds derived from algae.

\section{Antiviral Drugs From Algae as Alternative to Synthetic Drugs}

Algae are a natural source of compounds with antiviral properties, have proven efficiency against enveloped and nonenveloped viruses, this compounds and extracts from algae have inexpensive to obtain, especially those of marine origin (Alam et al., 2021). Furthermore, algae are an alternative resource to synthetic drugs, because algae have very low toxicity and some are non-toxic at doses that have a broad antiviral spectrum against several viruses and minimal side effects (Besednova et al., 2021). Among the benefits of algae, we can still mention that due

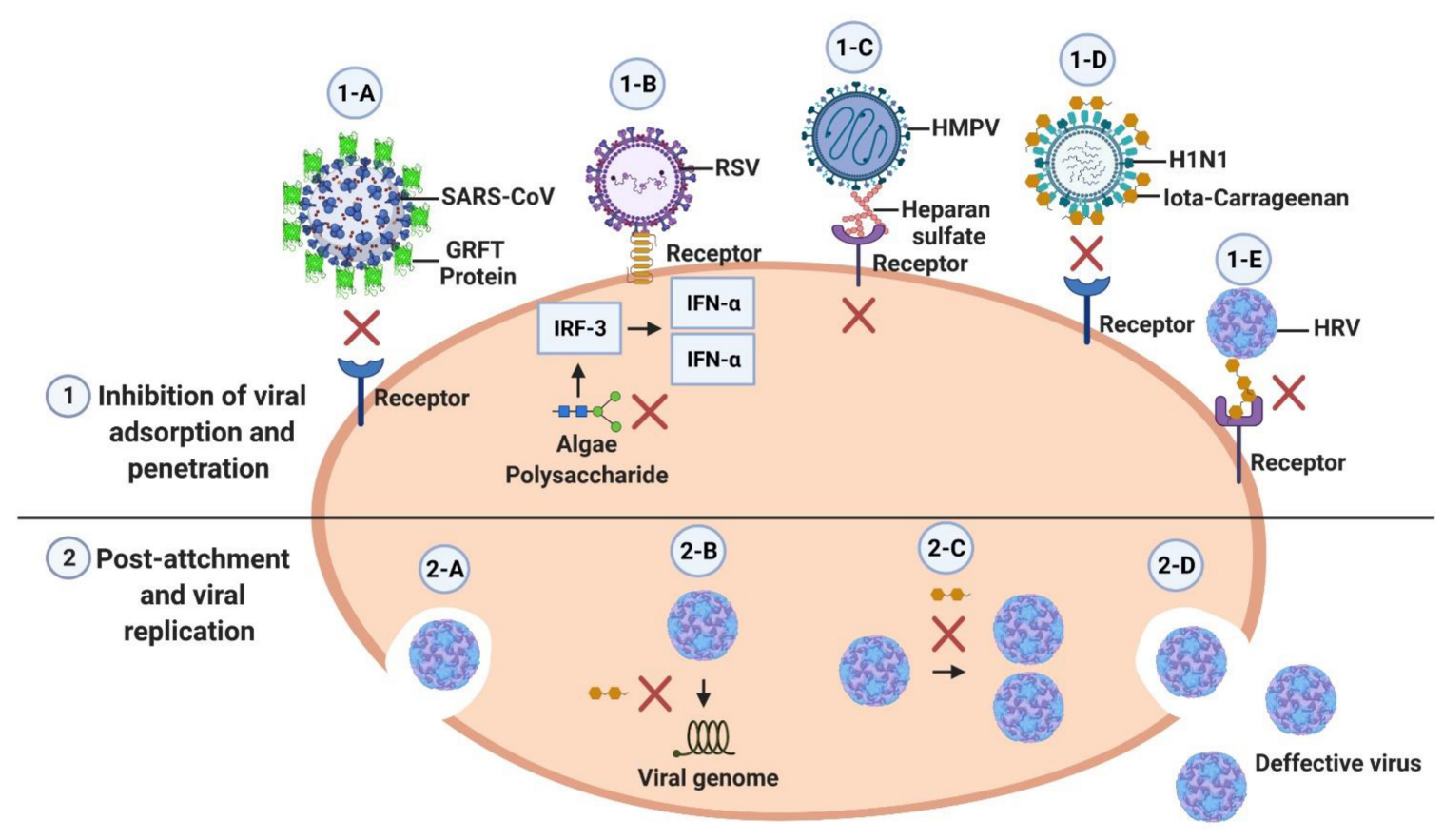

FIGURE 1 | The mechanisms of the action of natural compounds can be divided into two phases: before and after viral entry. 1-A: GRFT Protein from the Griffithsia sp. macroalgae binds to specific oligosaccharides in the virus envelope glycoproteins and block viral entry ( $O^{\prime} K e e f e$ et al., 2010). 1-B: Polysaccharides from Laminaria japonica enhance the expression level of IRF3 and the secretion of IFN alpha that results an antiviral activity against RSV. 1-C: The binding of HMPV to heparan sulfate involves charge-charge interactions; this blocks the binding of HMPV to the receptor and consequently inhibits the infection of cells (Klimyte et al., 2016) 0.1-D: lota-carrageenan from red algae has a long chain of negatively charged molecules that attract and capture positively charged viruses and prevent them from infecting cells (Leibbrandt et al., 2010; Eccles, 2020). 1-E: lota-carrageenan binds to the surface of rhinovirus and inhibits virus binding to cell receptors (Grassauer et al., 2008). 2-A: Viral entry. 2-B lota-carrageenan also has an inhibitory effect after the virus enters the cell, blocking the conformational changes of rhinovirus necessary for infection (2-B: uncoating and 2-C: replication) lota-carrageenan acts occludes virion surfaces involved in binding to cellular proteins required for the infectious process; this prevents replication and results in the viral particles produced being defective (Buck et al., 2006; Grassauer et al., 2008). 2-D: Exit of defective viral particles. 
to the diversity of molecules and their mechanisms of action, it inactivates viruses and block their action without causing resistance or selection of these organisms (Hamed et al., 2015).

\section{CONCLUSION}

Various compounds from algae have potent activities against viruses, and are strong candidates for the control and treatment of viruses that affect humans and animals. These bioactive compounds should be further explored for health applications, both in clinicals and the environmental. They are also promising for use as low toxicity sanitizers of high virucidal capacity. More studies are required both for prospecting algae for active molecules and for the development of products suitable for applications in viral control.

\section{REFERENCES}

Abdo, S. M., Hetta, M. H., El-Senousy, W. M., Salah El Din, R. A., and Ali, G. H. (2012). Antiviral activity of freshwater algae. J. Appl. Pharm. Sci. 2, $21-25$.

Agca, H., Akalin, H., Saglik, I., Hacimustafaoglu, M., Celebi, S., and Ener, B. (2021). Changing epidemiology of influenza and other respiratory viruses in the first year of COVID-19 pandemic. J. Infect. Public Health 14, 1186-1190. doi: 10.1016/j.jiph.2021.08.004

Alam, M. A., Parra-Saldivar, R., Bilal, M., Afroze, C. A., Ahmed, M. N., Iqbal, H., et al. (2021). Algae-derived bioactive molecules for the potential treatment of SARS-CoV-2. Molecules 26:2134. doi: 10.3390/molecules26082134

Anand, U., Bianco, F., Suresh, S., Tripathi, V., Núñez-Delgado, A., and Race, M. (2021). SARS-CoV-2 and other viruses in soil: an environmental outlook. Environ. Res. 198, 1-13. doi: 10.1016/j.envres.2021.111297

Balboa, E. M., Conde, E., Moure, A., Falqué, E., and Domínguez, H. (2013). In vitro antioxidant properties of crude extracts and compounds from brown algae. Food Chem. 138, 1764-1785. doi: 10.1016/j.foodchem.2012.11.026

Belgerson, D. V., Byrne, J. H., Mackey, S. L., Kandel, E. R., and Hawkins, R. D. (1997). K. C Mart n et a. Soc. Neurosci. Abstr. 31:125.

Besednova, N. N., Andryukov, B. G., Zaporozhets, T. S., Kryzhanovsky, S. P., Fedyanina, L. N., Kuznetsova, T. A., et al. (2021). Antiviral effects of polyphenols from marine algae. Biomedicines 9:200. doi: 10.3390/ biomedicines 9020200

Branyikova, I., Prochazkova, G., Potocar, T., Jezkova, Z., and Branyik, T. (2018). Harvesting of microalgae by flocculation. Fermentation 4, 1-12. doi: 10.3390/ fermentation 4040093

Buck, C. B., Thompson, C. D., Roberts, J. N., Müller, M., Lowy, D. R., and Schiller, J. T. (2006). Carrageenan is a potent inhibitor of papillomavirus infection. PLoS Pathog. 2:671-680. doi: 10.1371/journal.ppat.0020069

Cao, Y. G., Hao, Y., Li, Z. H., Liu, S. T., and Wang, L. X. (2016). Antiviral activity of polysaccharide extract from Laminaria japonica against respiratory syncytial virus. Biomed. Pharmacother. 84, 1705-1710. doi: 10.1016/j.biopha.2016.10.082

Carter, M. J. (2005). Enterically infecting viruses: pathogenicity, transmission and significance for food and waterborne infection. J. Appl. Microbiol. 98, 1354-1380. doi: 10.1111/j.1365-2672.2005.02635.x

Célia da Silva Lanna, M., Viancelli, A., Michelon, W., Castro Carvalho, S. V., de Almeida dos Reis, D., Fernandez de Salles, L. A., et al. (2019). Household-based biodigesters promote reduction of enteric virus and bacteria in vulnerable and poverty rural area. Environ. Pollut. 252, 8-13. doi: 10.1016/j.envpol.2019.05.104

Chacon, E., Acosta, D., and Lemasters, J. (1996). "Primary cultures of cardiac myocytes as in vitro models for pharmacological and toxicological assessments," in In Vitro Methods in Pharmaceutical Research, eds J. V. Castell and M. J. G. ómez-Lechón (Cambridge, MA: Academic Press), doi: 10.1016/b978012163390-5/50010-7

\section{AUTHOR CONTRIBUTIONS}

JR, RC, AC, IT, DR-L, and GF: original draft preparation and manuscript reviewing and editing. GF: final manuscript supervision. All authors contributed to the article and approved the submitted version.

\section{FUNDING}

This work was supported by the CAPES-DS fellowship.

\section{ACKNOWLEDGMENTS}

All authors acknowledged to Laboratory of Apllied Virology team at the University Federal of Santa Catarina.

Charoonnart, P., Worakajit, N., Zedler, J. A. Z., Meetam, M., Robinson, C., and Saksmerprome, V. (2019). Generation of microalga Chlamydomonas reinhardtii expressing shrimp antiviral dsRNA without supplementation of antibiotics. Sci. Rep. 9:3164. doi: 10.1038/s41598-019-39539-x

Chiu, Y. H., Chan, Y. L., Tsai, L. W., Li, T. L., and Wu, C. J. (2012). Prevention of human enterovirus 71 infection by kappa carrageenan. Antiviral Res. 95, 128-134. doi: 10.1016/j.antiviral.2012.05.009

Choi, Y., Kim, E., Moon, S., Choi, J. D., Lee, M. S., and Kim, Y. M. (2014). Phaeophyta extracts exhibit antiviral activity against feline calicivirus. Fish. Aquat. Sci. 17, 155-158. doi: 10.5657/FAS.2014.0155

Chotigeat, W., Tongsupa, S., Supamataya, K., and Phongdara, A. (2004). Effect of fucoidan on disease resistance of black tiger shrimp. Aquaculture 233, 23-30. doi: 10.1016/j.aquaculture.2003.09.025

Ciko, A. M., Jokić, S., Šubarić, D., and Jerković, I. (2018). Overview on the application of modern methods for the extraction of bioactive compounds from marine macroalgae. Mar. Drugs 16:348. doi: 10.3390/md16100348

Cirne-Santos, C. C., Barros, C., de, S., Nogueira, C. C. R., Azevedo, R. C., Yamamoto, K. A., et al. (2019). Inhibition by marine algae of chikungunya virus isolated from patients in a recent disease outbreak in rio de janeiro. Front. Microbiol. 10:2426. doi: 10.3389/fmicb.2019.02426

Deryabin, P. G., Garaev, T. M., Finogenova, M. P., Botikov, A. G., and Shibnev, V. A. (2014). Amino acid derivatives of adamantane carbocycle are capable of inhibiting replication of highly virulent avian influenza A/H5N1 virus. Bull. Exp. Biol. Med. 157, 62-65. doi: 10.1007/s10517-014-2492-2

Dias, D. A., Urban, S., and Roessner, U. (2012). A Historical overview of natural products in drug discovery. Metabolites 2, 303-336. doi: 10.3390/ metabo2020303

Eccles, R. (2020). Iota-carrageenan as an antiviral treatment for the common cold. Open Virol. J. 14, 9-15. doi: 10.2174/1874357902014010009

Eccles, R., Meier, C., Jawad, M., Weinmüllner, R., Grassauer, A., and PrieschlGrassauer, E. (2010). Efficacy and safety of an antiviral Iota-Carrageenan nasal spray: a randomized, double-blind, placebo-controlled exploratory study in volunteers with early symptoms of the common cold. Respir. Res. 11, 1-10. doi: 10.1186/1465-9921-11-108

El-Baz, F. K., El-Senousy, W. M., El-Sayed, A. B., and Kamel, M. M. (2013). In vitro antiviral and antimicrobial activities of Spirulina platensis extract. J. Appl. Pharm. Sci. 3, 52-56. doi: 10.7324/JAPS.2013.31209

Elizondo-Gonzalez, R., Cruz-Suarez, L. E., Ricque-Marie, D., Mendoza-Gamboa, E., Rodriguez-Padilla, C., and Trejo-Avila, L. M. (2012). In vitro characterization of the antiviral activity of fucoidan from Cladosiphon okamuranus against newcastle disease Virus. Virol. J. 9:307. doi: 10.1186/1743-422X-9-307

Eom, S. H., Moon, S. Y., Lee, D. S., Kim, H. J., Park, K., Lee, E. W., et al. (2015). In vitro antiviral activity of dieckol and phlorofucofuroeckol-A isolated from edible brown alga Eisenia bicyclis against murine norovirus. Algae 30, 241-246. doi: 10.4490/algae.2015.30.3.241 
Evans, A. S. (1982). Epidemiological Concepts and Methods. In Viral Infections of Humans. Berlin: Springer, 3-42. doi: 10.1007/978-1-4613-323 7-4_1

Fabregas, J., García, D., Fernandez-Alonso, M., Rocha, A. I., Gómez-Puertas, P., Escribano, J. M., et al. (1999). In vitro inhibition of the replication of haemorrhagic septicaemia virus (VHSV) and African swine fever virus (ASFV) by extracts from marine microalgae. Antiviral Res. 44, 67-73. doi: 10.1016/ s0166-3542(99)00049-2

Fayzunnessa, N., Morshed, M. A., Uddin, A., and Parvin, A. (2011). International journal of biomolecules and biomedicine (IJBB) In vivo study on the efficacy of hypoglycemic activity of Spirulina plantesis in long evan rats. Int. J. Biomol. Biomed.e 1, 27-33.

Feng, Y., Gao, L., Miao, J., Zhang, M., Zhang, C., Wang, X., et al. (2018). Human infection with a novel H7N9 avian influenza virus in Yunnan, China. J. Infect. 76, 98-101. doi: 10.1016/j.jinf.2017.08.001

Gheda, S. F., El-Adawi, H. I., and El-Deeb, N. M. (2016). Antiviral profile of brown and red seaweed polysaccharides against hepatitis C Virus. Iran. J. Pharm. Res. $15,483-491$.

Glass, C. A., Cash, J. C., and Mullen, J. (eds) (2020). "Coronavirus disease (COVID19)," in Family Practice Guidelines, (New York, NY: Springer Publishing Company), doi: 10.1891/9780826153425.0016b

Grassauer, A., Weinmuellner, R., Meier, C., Pretsch, A., Prieschl-Grassauer, E., and Unger, H. (2008). Iota-Carrageenan is a potent inhibitor of rhinovirus infection. Virol. J.l 5:107. doi: 10.1186/1743-422X-5-107

Hamed, I., Özogul, F., Özogul, Y., and Regenstein, J. M. (2015). Marine bioactive compounds and their health benefits: a review. Compr. Rev. Food Sci. Food Saf 14, 446-465. doi: 10.1111/1541-4337.12136

Hasui, M., Matsuda, M., Okutani, K., and Shigeta, S. (1995). In vitro antiviral activities of sulfated polysaccharides from a marine microalga (Cochlodinium polykrikoides) against human immunodeficiency virus and other enveloped viruses. Int. J. Biol. Macromol. 17, 293-297. doi: 10.1016/0141-8130(95)98 $157-\mathrm{T}$

Hayashi, T., Hayashi, K., Maeda, M., and Kojima, I. (1996). Calcium spirulan, an inhibitor of enveloped virus replication, from a blue-green alga Spirulina platensis. J. Nat. Prod. 59, 83-87. doi: 10.1021/np960017o

Hidari, K. I. P. J., Takahashi, N., Arihara, M., Nagaoka, M., Morita, K., and Suzuki, T. (2008). Structure and anti-dengue virus activity of sulfated polysaccharide from a marine alga. Biochem. Biophys. Res. Commun. 376, 91-95. doi: 10.1016/ j.bbrc.2008.08.100

Immanuel, G., Sivagnanavelmurugan, M., Marudhupandi, T., Radhakrishnan, S., and Palavesam, A. (2012). The effect of fucoidan from brown seaweed Sargassum wightii on WSSV resistance and immune activity in shrimp Penaeus monodon (Fab). Fish Shellf. Immunol. 32, 551-564. doi: 10.1016/j.fsi.2012.01. 003

Ishag, H. Z. A., Li, C., Huang, L., Sun, M., Wang, F., Ni, B., et al. (2013). Griffithsin inhibits Japanese encephalitis virus infection in vitro and in vivo. Arch. Virol. 158, 349-358. doi: 10.1007/s00705-012-1489-2

Jacobsen, C., Sørensen, A.-D. M., Holdt, S. L., Akoh, C. C., and Hermund, D. B. (2019). Source, extraction, characterization, and applications of novel antioxidants from seaweed. Ann. Rev. Food Sci. Technol. 10, 541-568. doi: 10.1146/annurev-food-032818-121401

Jothikumar, N., Cromeans, T. L., Sobsey, M. D., and Robertson, B. H. (2005). Development and evaluation of a broadly reactive taqman assay for rapid detection of hepatitis a virus. Appl. Environ. Microbiol. 71, 3359-3363. doi: 10.1128/AEM.71.6.3359-3363.2005

Kaufmann, B., and Christen, P. (2002). Recent extraction techniques for natural products: microwave-assisted extraction and pressurised solvent extraction. Phytochem. Anal. 13, 105-113. doi: 10.1002/pca.631

Kim, M., Yim, J. H., Kim, S. Y., Kim, H. S., Lee, W. G., Kim, S. J., et al. (2012). In vitro inhibition of influenza $\mathrm{A}$ virus infection by marine microalga-derived sulfated polysaccharide p-KG03. Antiviral Res. 93, 253-259. doi: 10.1016/j. antiviral.2011.12.006

Klimyte, E. M., Smith, S. E., Oreste, P., Lembo, D., and Dutch, R. E. (2016). Inhibition of human metapneumovirus binding to heparan sulfate blocks infection in human lung cells and airway tissues. J. Virol. 90, 9237-9250. doi: 10.1128/JVI.01362-16

Kumar Jha, R., and Zi-Rong, X. (2004). Biomedical compounds from marine organisms. Mar. Drugs 2, 123-146.
Leandro, A., Pereira, L., and Gonçalves, A. M. M. (2019). Diverse applications of marine macroalgae. Mar. Drugs 18:17. doi: 10.3390/md18010017

Leibbrandt, A., Meier, C., König-Schuster, M., Weinmüllner, R., Kalthoff, D., Pflugfelder, B., et al. (2010). Iota-carrageenan is a potent inhibitor of influenza a virus infection. PLoS One 5:e14320. doi: 10.1371/journal.pone.0014320

Levendosky, K., Mizenina, O., Martinelli, E., Jean-Pierre, N., Kizima, L., Rodriguez, A., et al. (2015). Griffithsin and carrageenan combination to target herpes simplex virus 2 and human papillomavirus. Antimicrob. Agents Chemother. 59, 7290-7298. doi: 10.1128/AAC.01816-15

Li, L., Yu, X., Zhang, H., Cheng, H., Hou, L., Zheng, Q., et al. (2019). In vitro antiviral activity of Griffithsin against porcine epidemic diarrhea virus. Virus Genes 55, 174-181. doi: 10.1007/s11262-019-01633-7

Linnakoski, R., Reshamwala, D., Veteli, P., Cortina-Escribano, M., Vanhanen, H., and Marjomäki, V. (2018). Antiviral agents from fungi: diversity, mechanisms and potential applications. Front. Microbiol. 9:2325. doi: 10.3389/fmicb.2018. 02325

Lozano, I., Wacyk, J. M., Carrasco, J., and Cortez-San Martín, M. A. (2016). Red macroalgae Pyropia columbina and Gracilaria chilensis: sustainable feed additive in the Salmo salar diet and the evaluation of potential antiviral activity against infectious salmon anemia virus. J. Appl. Phycol. 28, 1343-1351. doi: $10.1007 / \mathrm{s} 10811-015-0648-8$

Lusvarghi, S., and Bewley, C. (2016). Griffithsin: an antiviral lectin with outstanding therapeutic potential. Viruses 8:296. doi: 10.3390/v8100296

Mandal, P., Mateu, C. G., Chattopadhyay, K., Pujol, C. A., Damonte, E. B., and Ray, B. (2007). Structural features and antiviral activity of sulphated fucans from the brown seaweed Cystoseira indica. Antiviral Chem. Chemother. 18, 153-162. doi: 10.1177/095632020701800305

Marjomäki, V., Turkki, P., and Huttunen, M. (2015). Infectious entry pathway of enterovirus B species. Viruses 7, 6387-6399. doi: 10.3390/v7122945

Matsuhiro, B., Conte, A. F., Damonte, E. B., Kolender, A. A., Matulewicz, M. C., Mejías, E. G., et al. (2005). Structural analysis and antiviral activity of a sulfated galactan from the red seaweed Schizymenia binderi (Gigartinales, Rhodophyta). Carbohyd. Res. 340, 2392-2402. doi: 10.1016/j.carres.2005.08.004

Mazumder, S., Ghosal, P. K., Pujol, C. A., Carlucci, M. J., Damonte, E. B., and Ray, B. (2002). Isolation, chemical investigation and antiviral activity of polysaccharides from Gracilaria corticata (Gracilariaceae, Rhodophyta). Int. J. Biol. Macromol.s 31, 87-95. doi: 10.1016/S0141-8130(02)00070-3

Medina, R. A., and García-Sastre, A. (2011). Influenza A viruses: new research developments. Nat. Rev. Microbiol. 9, 590-603. doi: 10.1038/nrmicro2613

Mendes, G., Soares, A. R., Martins, F. O., Albuquerque, M. C. M., Costa, S. S., Yoneshigue-Valentin, Y., et al. (2010). Antiviral activity of the green marine alga Ulva fasciata on the replication of human metapneumovirus. Rev. Inst.e Med. Trop. São Paulo 52, 3-10. doi: 10.1590/s0036-46652010000100001

Meuleman, P., Albecka, A., Belouzard, S., Vercauteren, K., Verhoye, L., Wychowski, C., et al. (2011). Griffithsin has antiviral activity against hepatitis C virus. Antimicrob. Agents Chemother. 55, 5159-5167. doi: 10.1128/AAC.0063311

Micewicz, E. D., Cole, A. L., Jung, C. L., Luong, H., Phillips, M. L., Pratikhya, P., et al. (2010). Grifonin-1: a small HIV-1 entry inhibitor derived from the algal lectin, griffithsin. PLoS One 5:e14360. doi: 10.1371/journal.pone.0014360

Montalvão, S., Demirel, Z., Devi, P., Lombardi, V., Hongisto, V., Perälä, M., et al. (2016). Large-scale bioprospecting of cyanobacteria, micro- and macroalgae from the Aegean Sea. New Biotechnol. 33, 399-406. doi: 10.1016/j.nbt.2016.02. 002

Mori, T., O’Keefe, B. R., Sowder, R. C., Bringans, S., Gardella, R., Berg, S., et al. (2005). Isolation and characterization of Griffithsin, a novel HIV-inactivating protein, from the red alga Griffithsia sp. J. Biol. Chem.y 280, 9345-9353. doi: $10.1074 /$ jbc.M411122200

O'Keefe, B. R., Giomarelli, B., Barnard, D. L., Shenoy, S. R., Chan, P. K. S., McMahon, J. B., et al. (2010). Broad-spectrum in vitro activity and in vivo efficacy of the antiviral protein griffithsin against emerging viruses of the family coronaviridae. J. Virol. 84, 2511-2521. doi: 10.1128/jvi. 02322-09

O'Keefe, B. R., Vojdani, F., Buffa, V., Shattock, R. J., Montefiori, D. C., Bakke, J., et al. (2009). Scaleable manufacture of HIV-1 entry inhibitor griffithsin and validation of its safety and efficacy as a topical microbicide component. Proc. Natl. Acad. Sci. U.S.A. 106, 6099-6104. doi: 10.1073/pnas.09015 06106 
Olival, K. J., Hosseini, P. R., Zambrana-Torrelio, C., Ross, N., Bogich, T. L., and Daszak, P. (2017). Host and viral traits predict zoonotic spillover from mammals. Nature 546, 646-650. doi: 10.1038/nature22975

Onofrejová, L., Vašíčková, J., Klejdus, B., Stratil, P., Mišurcová, L., Kráčmar, S., et al. (2010). Bioactive phenols in algae: the application of pressurized-liquid and solid-phase extraction techniques. J. Pharm. Biomed. Anal. 51, 464-470. doi: 10.1016/j.jpba.2009.03.027

Patel, G., Huprikar, S., Factor, S. H., Jenkins, S. G., and Calfee, D. P. (2008). Outcomes of carbapenem-resistant Klebsiella pneumoniae infection and the impact of antimicrobial and adjunctive therapies. Infect. Control Hosp. Epidemiol. 29, 1099-1106. doi: 10.1086/592412

Pavliga, S. N., Kompanets, G. G., and Tsygankov, V. Y. (2016). The experimental research (in vitro) of carrageenans and fucoidans to decrease activity of hantavirus. Food Environ. Virol. 8, 120-124. doi: 10.1007/s12560-016-9 233-9

Ponce, N. M. A., Pujol, C. A., Damonte, E. B., Flores, M. L., and Stortz, C. A. (2003). Fucoidans from the brown seaweed Adenocystis utricularis: extraction methods, antiviral activity and structural studies. Carbohyd. Res. 338, 153-165. doi: 10.1016/S0008-6215(02)00403-2

Prasse, C., Schlüsener, M. P., Schulz, R., and Ternes, T. A. (2010). Antiviral drugs in wastewater and surface waters: a new pharmaceutical class of environmental relevance? Environ. Sci. Technol. 44, 1728-1735. doi: 10.1021/es903216p

Rigotto, C., Hanley, K., Rochelle, P. A., De Leon, R., Barardi, C. R. M., and Yates, M. V. (2011). Survival of adenovirus types 2 and 41 in surface and ground waters measured by a plaque assay. Environ. Sci. Technol. 45, 4145-4150. doi: 10.1021/es103922r

Rosa, G. P., Tavares, W. R., Sousa, P. M. C., Pagès, A. K., Seca, A. M. L., and Pinto, D. C. G. A. (2020). Seaweed secondary metabolites with beneficial health effects: an overview of successes in in vivo studies and clinical trials. Mar. Drugs 18:8. doi: $10.3390 / \mathrm{md} 18010008$

Rosales-Mendoza, S., García-Silva, I., González-Ortega, O., Sandoval-Vargas, J. M., Malla, A., and Vimolmangkang, S. (2020). The potential of algal biotechnology to produce antiviral compounds and biopharmaceuticals. Molecules 25:4049. doi: 10.3390/molecules25184049

Santoyo, S., Plaza, M., Jaime, L., Ibañez, E., Reglero, G., and Señorans, F. J. (2010). Pressurized liquid extraction as an alternative process to obtain antiviral agents from the edible microalga Chlorella vulgaris. J. Agric. Food Chem. 58, 8522-8527. doi: 10.1021/jf100369h

Silva, T., Salomon, S., Hamerski, L., Walter, J., Menezes, B., Siqueira, J. E., et al. (2018). Inhibitory effect of microalgae and cyanobacteria extracts on influenza virus replication and neuraminidase activity. PeerJ 6:e5716. doi: 10.7717/peerj. 5716

Sivagnanavelmurugan, M., Marudhupandi, T., Palavesam, A., and Immanuel, G. (2012). Antiviral effect of fucoidan extracted from the brown seaweed, Sargassum wightii, on shrimp penaeus monodon postlarvae against white spot syndrome virus. J. World Aquac. Soc. 43, 697-706. doi: 10.1111/j.1749-7345. 2012.00596.x

Spolaore, P., Joannis-Cassan, C., Duran, E., and Isambert, A. (2006). Commercial applications of microalgae. J. Biosci. Bioeng. 101, 87-96. doi: 10.1263/jbb.101.87

Takebe, Y., Saucedo, C. J., Lund, G., Uenishi, R., Hase, S., Tsuchiura, T., et al. (2013). Antiviral lectins from red and blue-green algae show potent in vitro and in vivo activity against hepatitis C Virus. PLoS One 8:e64449. doi: 10.1371/journal.pone. 0064449
Talarico, L. B., and Damonte, E. B. (2007). Interference in dengue virus adsorption and uncoating by carrageenans. Virology 363, 473-485. doi: 10.1016/j.virol. 2007.01.043

Talarico, L. B., Zibetti, R. G. M., Faria, P. C. S., Scolaro, L. A., Duarte, M. E. R., Noseda, M. D., et al. (2004). Anti-herpes simplex virus activity of sulfated galactans from the red seaweeds Gymnogongrus griffithsiae and Cryptonemia crenulata. Int. J. Biol.l Macromol.s 34, 63-71. doi: 10.1016/j.ijbiomac.2004.03. 002

Taylor, L. H., Latham, S. M., and Woolhouse, M. E. J. (2001). Risk factors for human disease emergence. Philos. Trans. R. Soc. B 356, 983-989. doi: 10.1098/rstb.2001. 0888

Trejo-Avila, L. M., Morales-Martínez, M. E., Ricque-Marie, D., Cruz-Suarez, L. E., Zapata-Benavides, P., Morán-Santibañez, K., et al. (2014). In vitro anti-canine distemper virus activity of fucoidan extracted from the brown alga Cladosiphon okamuranus. Virus Dis. 25, 474-480. doi: 10.1007/s13337-014-0228-6

Vichai, V., and Kirtikara, K. (2006). Sulforhodamine B colorimetric assay for cytotoxicity screening. Nat. Protoc. 1, 1112-1116. doi: 10.1038/nprot.2006.179

Victoria, M., Rigotto, C., Moresco, V., de Abreu Corrãaa, A., Kolesnikovas, C., Leite, J. P. G., et al. (2009). Assessment of norovirus contamination in environmental samples from Florianopolis City, Southern Brazil. J. Appl. Microbiol. 109, 231-238. doi: 10.1111/j.1365-2672.2009.04646.x

Wang, S., Wang, W., Hao, C., Yunjia, Y., Qin, L., He, M., et al. (2018). Antiviral activity against enterovirus 71 of sulfated rhamnan isolated from the green alga Monostroma latissimum. Carbohyd. Polym. 200, 43-53. doi: 10.1016/j.carbpol. 2018.07.067

Wang, W., Wang, S.-X., and Guan, H.-S. (2012). The antiviral activities and mechanisms of marine polysaccharides: an overview. Mar. Drugs 10, 27952816. doi: 10.3390/md10122795

Ye, Z. W., Yuan, S., Yuen, K. S., Fung, S. Y., Chan, C. P., and Jin, D. Y. (2020). Zoonotic origins of human coronaviruses. Int. J. Biol. Sci. 16, 1686-1697. doi: $10.7150 /$ ijbs. 45472

Yoon, B. K., Jeon, W., Sut, T. N., Cho, N., and Jackman, A. (2021). Stopping membrane-enveloped viruses with nanotechnology strategies: toward antiviral drug development and pandemic preparedness. ACS Nano 15, 125-148. doi: 10.1021/acsnano.0c07489

Conflict of Interest: The authors declare that the research was conducted in the absence of any commercial or financial relationships that could be construed as a potential conflict of interest.

Publisher's Note: All claims expressed in this article are solely those of the authors and do not necessarily represent those of their affiliated organizations, or those of the publisher, the editors and the reviewers. Any product that may be evaluated in this article, or claim that may be made by its manufacturer, is not guaranteed or endorsed by the publisher.

Copyright (c) 2022 Reis, Cadamuro, Cabral, Thaís da Silva, Rodríguez-Lázaro and Fongaro. This is an open-access article distributed under the terms of the Creative Commons Attribution License (CC BY). The use, distribution or reproduction in other forums is permitted, provided the original author(s) and the copyright owner(s) are credited and that the original publication in this journal is cited, in accordance with accepted academic practice. No use, distribution or reproduction is permitted which does not comply with these terms. 